\title{
"Jerusalem" as an Expression of What Is Sacred in Music: Restoration Tendencies in Nineteenth-Century Church Music
}

The last decades of the nineteenth century were an era of renewal for church service plans and church music traditions in Protestant parts of Europe. This was also a period of restauration of historical forms of song and music. This article examines such a restauration project among Lutherans in the German Kingdom of Bavaria, which eventually rippled into Scandinavia. These thoughts of restoration and renewal were expressed officially in journals of liturgy and church music, in Germany and Sweden. It is a less known fact that images inspired by the ancient temple cult on Mount Zion in Jerusalem came to play a certain part in this work. The image of Jerusalem helped shape the restoration of church music in nineteenth-century Lutheran Europe, and this chapter examines how "Jerusalem" became a code to church music in late nineteenth-century Germany and Scandinavia.

New spiritual trends were on the rise in the Protestant areas of Europe in the second half of the nineteenth century. Some of them took root in Scandinavian national churches and had a formative influence on sermons and pious life in these Protestant countries. Others led to separation from the official established religion and to the establishment of independent congregations. Pietism, with its strong emphasis on repentance and a personal spiritual life, was a driving force in this development. The ideal of clerical eloquence flourished in services, as well as in edifying meetings. Sunday service in the Norwegian national church was worship, of course, but the service was not least regarded as a speech act in which the cleric was the teacher and the congregation were the listeners. Hence, the preacher was the one who declared the sinful person justified before God. Primarily, this should be brought about by the strength of the spoken words; not through a pious, liturgical life.

A large variety of Christian musical forms, connected with different forms of Christian spiritualty, arose in the wake of this development. Evangelical revivalism generally favoured a repertoire of songs with an emotional appeal. It is a

Note: I would like to thank Lindie Landmark for translating this chapter from Norwegian into English. She has also translated the German and Swedish original texts into English.

Svein Erik Tandberg, PhD, Church Musician and Independent Scholar, Tønsberg, Norway 
well-known fact that the word Jerusalem is often to be found in these lyrics as an example of a religious person's longing for heaven. The Lutheran national churches had their own hymn tradition, but the melodic material had been changed considerably over the years. In this picture, hymnody and music were to serve primarily as a worthy frame around the sermon. They were hardly seen as having any substantial signification; for the most part, they were just looked upon as ornamental aesthetics.

At the same time, this was an era of renewal of church service plans and church music traditions, and it was also an era of restoration of historical forms of song and music. The image of Jerusalem played a significant role in shaping the restoration of church music in nineteenth-century Lutheran Europe, and "Jerusalem" became a code to church music in late nineteenth-century Germany and Scandinavia.

\section{Siona - Journal of Liturgy and Church Music}

To begin with, the restoration project was officially reflected in Siona, a German journal of liturgy and church music, which was established in 1876. The journal aimed at shedding light on the practical theological and musical topics, which related specifically to the confessional character and the aesthetic foundation of services in the Evangelical Lutheran Church. A few years later, two similar journals were established in Sweden, yet these publications were short-lived. These journals were named Motettaftonen [The Motet Evening] and Tidning för kyrkomusik [Journal for Church Music], and they were inspired apparently by Siona. All these publications acted as a mouthpiece for a spiritual movement that emphasized liturgical and musical form in relation to church service, and they distanced themselves from the romanticisation and the emphasis on feelings towards the topos of Jerusalem found in Pietism.

It is the "beautiful worship" of both the past and the future on Mount Zion we visualize when we begin the liturgical work. This journal is now being distributed with the prayer that also our friends and readers be lifted up unto Zion; that they find their dwelling in the hallowed halls of Mount Zion, and let themselves be filled with the spirit of sacrifice and worship, as it prevailed on Mount Zion. At the same time, it is our aim and our prayer that it will revive the distinctive character of the Evangelical Church. That is why it calls itself "the Voice of Zion," Siona. ${ }^{1}$

\footnotetext{
1 "Die 'schönen Gottesdienste' Zions in Vergangenheit und Zukunft schweben unsere Seele vor, indem wir die liturgische Arbeit beginnen. Daß auch unsere Leser und Freunde sich gen Zion erheben, in hehren Hallen weilen und mit dem Geiste des Opfers und Gebetes sich erfüllen mögen, wie er auf Zion waltet: das ist unser Ziel und Bitte, mit welcher diese Zeitschrift ausgehen will, das gottesdienstliche Wesen der evangelischen Kirche zu beleben. Darum nennt sie sich 'Zions=Stimme,' Siona.” Max Herold, "Siona" in Siona. Monatsschrift für Liturgie und Kirchenmusik zur Hebung des gottesdienstlichen Lebens, eds. L. Schöberlein, M. Herold and E. Krüger (Gütersloh: G. Bertelsmann, 1876).
} 


\section{1}

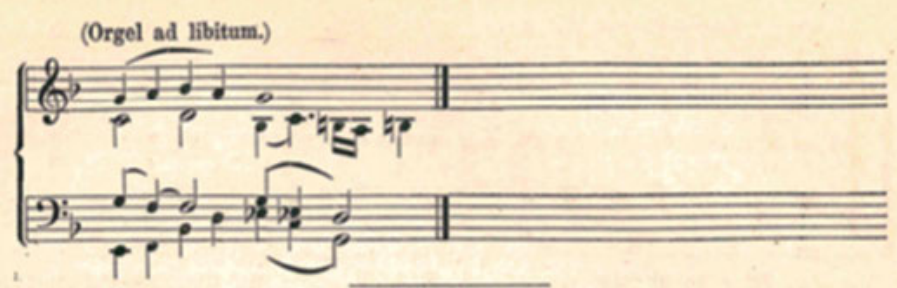

2) Sanetus summum.

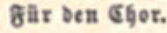

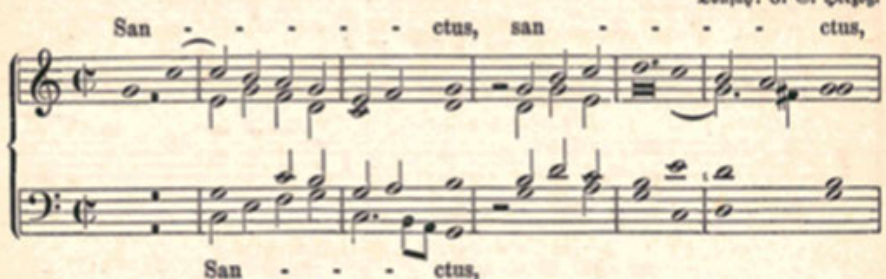

San - - ctus,

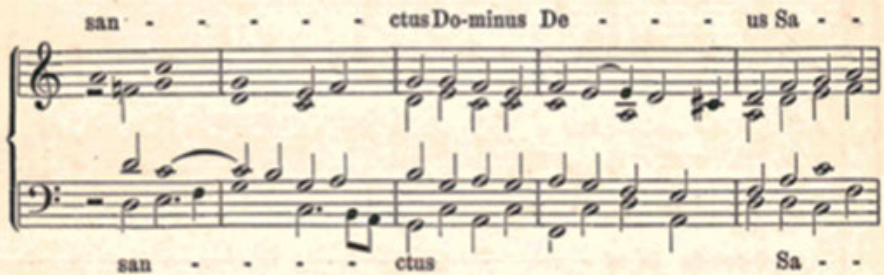

Sa - -

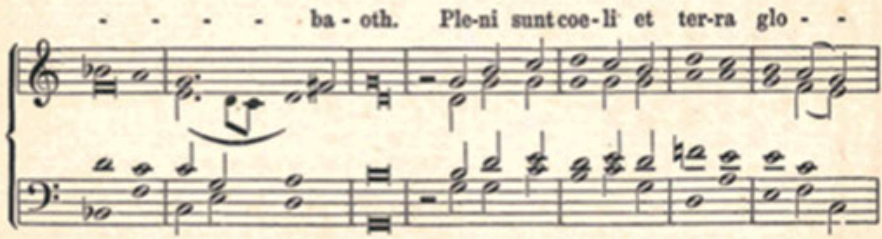

- - ba-

ri -. a tu . - a. 0. sanna in ex - cel ...

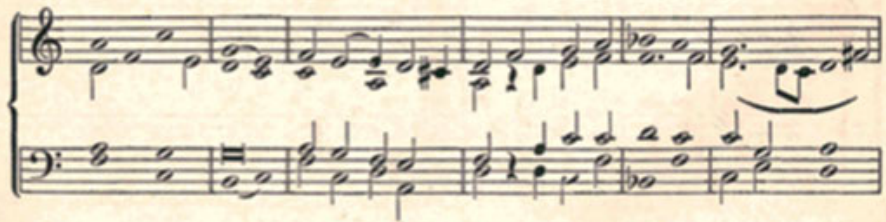

Fig. 14.1: Sanctus Summum, by Johann Georg Herzog, printed in Siona (1879). An arrangement for mixed choir of a classical church melody, and a typical example of vocal music designed for Bavarian Lutheran worship in the second part of the nineteenth century. Written in an archaic style by J.G. Herzog (1822-1909), one of the foremost Lutheran church musicians of this period, and a central figure in the Bavarian restoration movement. 
With these words, the theologian Max Herold (1840-1921) begins his editorial in the first edition of the journal Siona in $1876 .^{2}$ The author was a driving force among those who tried to renew the liturgy of the Lutheran churches in Germany during this period. At the time, he was serving as a minister in the city of Schwabach in Bavarian Middle Franconia. Alongside the theologian Wilhelm Löhe (1808-1872), Herold was at the forefront in the fields of liturgy, hymnody, and church music in Bavaria's Lutheran Church. ${ }^{3}$

In the year 1876, Siona is the first German literary journal, and probably the first European journal altogether which discusses church music and liturgical subjects. The editorial line of the journal was to view these subject areas as interdependent fields. ${ }^{4}$ In the following years, we find a parade of prominent theologians and church musicians among the contributors to Siona. In particular, Herold himself played an increasingly important part in renewing the Lutheran service; also internationally. This was, not least, a result of his many articles in Siona, since the journal was also distributed abroad after only a short while.

Soon, Herold received groups of people interested in the subject from other countries, including Russia, Hungary, North America, and Sweden. They came to Schwabach to draw new inspiration for their own liturgical life, from the work on liturgy that Herold was leading in Bavaria and Germany. ${ }^{5}$ Above all, the liturgical renewal movement in the Lutheran Church of Bavaria became normative for many sister churches, both inside and outside the old German Empire.

\section{An Interdenominational Flavour}

Siona's first chief editor was Ludwig Schöberlein (1813-1881), a professor of systematic theology and liturgics at the University of Göttingen. ${ }^{6}$ Schöberlein was, furthermore, a member of the Hymnal Revision Committee and the Committee on Liturgy of the Hannoverische Landeskirche [the Hanoverian Regional Church]. He also came to have an influence on the liturgical development within this German region.

2 Herold, "Siona."

3 Oskar Stollberg, Johann Georg Herzog in seinen Briefen an Max Herold 1865-1908 (München: Kaiser Verlag, 1978), 112-6; cf. also Svein Erik Tandberg, "Fra kirkestil til sjangerpluralisme. Historien som speil for dagens kirkemusikk," in Gudstjeneste à la carte. Liturgireformen i Den norske kirke, eds. Anne Haugland Balsnes, Solveig Christensen, Jan Terje Christoffersen and Hallvard Olavson Mosdøl (Oslo: Verbum Akademisk, 2015), 232.

4 In later terminology, this might be regarded as a type of "aesthetic theology."

5 Stollberg, Johann Georg Herzog in seinen Briefen an Max Herold 1865-1908, 113.

6 At this time, Herold was a member of the editorial staff, but he held an important position when it comes to the academic content of the journal. Over the years, many of the articles in Siona were published anonymously. However, Herold is regarded as author of them. 
Through his journal, he was a keen supporter of using Gregorian chant and polyphonic choir music in the Lutheran service, provided the texts were in German. Schöberlein's promotion of these originally "Catholic" music forms, gave Siona a rather interdenominational flavour, which, in turn, led Siona to be regarded as an ecumenical journal for liturgy and church music. The fact that many articles were published under the headline ecumenical expressed this view.

\section{History as Norm}

In his first editorial in Siona, Herold wrote that history must be considered the true norm in liturgical matters. As we have seen, he drew the historical lines far back in time: to the temple cult of ancient Israel on Mount Zion in Jerusalem. He pointed out connections as well as differences in the traditional perception within Judaism of Israel being Gods chosen people, and the perception of church in the New Testament. Furthermore, he emphasized the fact that it will not be possible to achieve a deeper understanding of the cult of the New Testament without a thorough understanding of temple worship on Mount Zion, as described in the Old Testament.

Herold argued that the temple worship in Jerusalem originated from a commandment, because it was on Mount Zion that God dwelt among his people (Exod 25:8, 26:6). There he disclosed himself and spoke to Israel (Exod 29; Num 9). There he received the sacrifice of the priests as atonement for the sins of the people and as praise of his grace and glory. According to Herold, this worship was sacrificial to the core; sacrificial and sacerdotal by nature.

In Herold's mind, there was little in contemporary Protestant preaching services that corresponded to the celebration in the temple of Jerusalem, since Old Testament worship "preached" through its actions. The priests would be allowed to speak to the people in the temple only on rare occasions. Teaching was to take place in the synagogue. Nevertheless, God "spoke" to his people on Mount Zion and through the thousand things.

Even though everything originating on Mount Zion had been fulfilled through Christianity and the New Covenant, temple worship would have to serve as an example for all true Christian liturgical celebration, because it was the origin of worship in the Primitive Church. All cultic terms and forms of the Primitive Church originated from the Old Testament worship. According to Herold, this had also been an influence on the Evangelical service, and even more so than many of his Lutheran co-religionists would imagine. ${ }^{7}$

7 Herold, "Siona." 


\section{An Archetype of Sacred Song}

Just as was the case in the temple worship in Jerusalem, Herold argues that the music must be sacred in its character, because it is bearer of holy content. He points out that King David was the great master of poetry and music - he was the one who introduced song and music into the temple worship on Mount Zion, and, several thousand years ago, the one who implemented the same norms that Siona would now promote. Herold therefore insists that David must be regarded as the archetype when sacred song is concerned. Herold describes how many of David's psalms are still sung, whether they be taken straight from the Bible or are sung in re-created forms. David's authority as "royal singer" is also evidenced by the fact that he is often portrayed on organ prospects. According to Herold, David's name and memory are often honoured in the preface of hymnals and prayer books.

In another article ${ }^{8}$ in the above-mentioned first edition of Siona, which was also a request for readers to subscribe, Herold accounted for the journal's ideas on church music:

However, when we not only look to liturgy, but also wish to see it in connection with church music, we will discover requirements not to be underestimated. Church music is only occasionally considered in regular journals of music; there is a lack of a genuine way of understanding and assessing it, and of clearer basic principles of the content and place of music in the church. However, liturgy itself constitutes such a solid basis and the right norm. Church music is completed in its sacred beauty in that it is seen as religious art of music. This is how liturgy and music are interdependent; this is how they further and complement each other. ${ }^{9}$

Herold describes this as the basis of Siona's viewpoint on church music. He points out that there is much in his time pretending to be church music, which, however, in no way bears the distinctive mark of sacred art. It just exhibits private sentimentalism. Religious music of this type can hardly be seen as a common expression of the faith of the congregation. When it comes to choral music and church song, he writes that the church has had its classical eras, and that the valuable music of these eras would have to regain its position in the services. Such historical works of music, in

8 Max Herold, "Prospectus," in Siona. Monatsschrift für Liturgie und Kirchenmusik zur Hebung des gottesdienstlichen Lebens, eds. L. Schöberlein, M. Herold and E. Krüger (Gütersloh: G. Bertelsmann, 1876). 9 "Wenn wir aber mit dem Blick auf die Liturgie noch den auf die Kirchenmusik verbinden, so wird auch nach dieser Seite das vorhandene Bedürfnis nicht verkannt werden können. Denn in den allgemeinen Musikzeitungen wird die Kirchenmusik theils nur nebenbei berücksichtigt, theils pflegt es an den wahren Principien für deren Auffassung und Beurtheilung und an klaren Grundfäßen für ihre kirchliche Verwendung zu fehlen. Aber eben die Liturgie ist es, welche hiefür den sichern Ausgangspunkt und den richtigen Maßstab darbietet - ebenso wie hinwiederum sie selbst die Vollendung ihrer heiligen Schönheit erst durch die Mitaufnahme der kirchlichen Tonkunst gewinnt. So fördern, bedingen und ergänzen sich gegenseitig Liturgie und Kirchenmusik.” Herold, "Prospectus.” 
bigger and smaller forms, should be models for composers of the day if they aim at creating music that can find its rightful place in church service (Fig. 14.1). Herold emphasizes that, if music can be evaluated as sacred, it has to meet distinct criteria of style and form. In this, tradition sets the standard.

In short, Herold believes that the historical lines must first be traced back to the temple worship and its music on Mount Zion, before the readers, in turn, can direct their attention to the situation of the day. The cultic, as well as the musical roots are present in the Old Testament. In that respect, Jerusalem becomes a code to church music, and Siona gives church music a central role in the synthesis of the historical and heavenly Jerusalem. Church music began on Mount Zion, and should, by virtue of its liturgical character, lead to a purification process with a sting against all non-liturgical and non-church excrescences.

\section{An Established Renewal Movement}

In the early nineteenth century, Lutherans in Bavaria had already begun the process of renewing their liturgy, but the movement did not get its own journal until 1876. The basis of this liturgical work was the so-called "Erlangen-theology." Besides being an Erfahrungstheologie [experiential theology] - which underlines that the content of the Scripture and each person's salvation history are in accordance with each other - the Erlangen theological viewpoint was characterized by an emphasis on historical continuity. That meant, among other things, that the prophecies of the Old Testament not only had to be regarded as a prediction or presentiment, but also as a deeper interpretation of occurrences of the present day. It follows that history points to something outside itself, to that which once shall be completed. The Scriptures as a whole are therefore regarded as a consistent salvation history where the Old Testament points to Christ, and the New Testament points to the completion of salvation history. Thus, there is a simultaneity in all these texts. ${ }^{10}$ This simultaneity appears, evidently, to be the basic vision for Siona.

Herold also points out that the new journal stands on the solid ground of the Reformation; totally and completely. As an Evangelical journal, Siona wishes to strengthen personal faith and Christian freedom within the congregations. Furthermore, celebration of the liturgy must be rooted in the principles of the sixteenth century, i.e. in the liturgical forms of the Reformation.

Consequently, it is Siona's view that a full restoration of the Protestant service arrangements is neither possible nor in accordance with the requirements of the day. Herold claims that the reason for this is that the Evangelical church has an ongoing

10 Cf. Bengt Hägglund, Teologins Historia. En dogmhistorisk översikt (Lund: CWK Gleerups Förlag, 1971), 348. 
urge to freedom as well a desire to exist within a suitable organizational framework; yet always on historical ground. By freedom, Herold claims that church service must be free of any external ritualistic force:

Our church faces a great task: modelled on an evangelical example, to cleanse the Christian service from all worldly and false Christian elements related to form and content. This must partly be done in light of the conditions that have distinguished church services in recent years, and with our attention directed to the past: to the original form of service in the Apostolic Age; partly considering the development of this celebration within the Old Catholic Church, both Greek and Roman. This last element is especially urgent in order to create a counterweight to the hegemony of sermons, in addition to giving more room for reading of the Scripture, singing and prayer. Our object is to promote the worshipping and sacramental character of church services. ${ }^{11}$

In this way, we might say that Herold formulates a piece of liturgical theology based on his imagined idea of the service of the Old Testament as a main theme. There are no sources that shed light on the music performed at the Temple in Jerusalem, and we have no way of knowing what worship music in the Temple sounded like. In other words, the music of the Old Testament remains unknown to us as a resonant artifact. Herold must have been well aware of this predicament when he formulated his theology. Herold's approach to the music of the old Jerusalem - an approach he shared with many of his contemporary music-restoration ideologists whom were also "Jerusalem romantics" - was therefore founded on an imagined and illusory basis. Herold seems to use his idea of the Old Testament service and music, both as a framework of understanding, and as an ideological intention of renewing the church service in his age. Such a renewed cult that Herold advocates in his editorial, is in principle the "old" Lutheran mass with communion every Sunday. For church music this renewal meant embracing fully the hymns of the Reformation and the vocal polyphony of the Renaissance, and in part the Gregorian chant tradition. "Renewal" should basically be regarded both as a restructuring and purgative process.

11 "Und es ist in unserer Kirche die große Aufgabe gestellt, ihren Gottesdienst auf den reformatorischen Grundlagen, wie im Hinblick auf seine spätere Entwickelung so zumal im Rückblick auf die apostolische Urgestalt des christlichen Gottesdienstes und auf seine Weiterbildung in der altkatholischen Kirche griechisch= und römischerseits, an der Hand der evangelischen Principien theils von allem Weltlichen und Falschchristlichen in Form und Inhalt zu reinigen, theils mit den aus der Vergangenheit und Gegenwart dargebotenen Mitteln nach allen Seiten weiter und gleichmäßiger auszubauen, insonderheit gegenüber einer einseitigen Predigtherrschaft den Elementen reicherer Schriftlesung, des Gesangs und Gebets, überhaupt der Anbetung sowie dem sakramentalen Wesen der kirchlichen Feier zur Geltung zu verhelfen." Herold, "Prospectus." 


\section{Perceptible Expressions of the Sacred and the Holy}

Through these two articles in the first edition of Siona, Herold paints his nineteenth-century picture of Jerusalem and Mount Zion as original forms of the holy and the sacred; in liturgy as well as in church music. Language and message are both unmistakeably coloured by the Romantic and idealistic ideas of the nineteenth century. The description of the temple worship in Jerusalem as a biblical idyll more or less, is characteristic of this Romantic-idealistic current. The method was, however, an ad fontes-strategy. Renewal was to be attained by creating service arrangements that managed to link the past and the present to the future. Herold's fundamental approach to liturgical issues was the concept of the "sacramental" Jerusalem. He looked upon liturgy as a perceptible entity. Since church music was a perceptible art form that also represented an invisible reality, its object was to form a link between these dimensions of time; therefore, it had to dissociate itself from such biased arbitrariness and partiality.

Herold viewed this as determining for the sacred identity of music, whether it was composed in what he refers to as the classical eras of church music, or it was composed in his own time. The aesthetic basis was considered obvious: Music was to carry the joint worship and celebration of the congregation. Only then, it could be part of the eschatological character of liturgy; enabling the people of God, through seeing the historical Jerusalem, to behold the new and heavenly Jerusalem.

In music, the notion of "pure" (i.e. modal) harmonies and lively rhythms served as an expression of sanctity. To a large degree, these were to imitate forms of historical sacred music. Viewing the celebration of service and church music in a temple perspective thereby became a substantial conceptual basis for Siona. It became a necessary premise for all work with liturgy and church music. The code word was restoration.

In Herold's opinion, there was a line through history - a line that would also be determining for Christian celebration of service. He sums up the objects of his journal as follows: 1) Promoting interest and knowledge about issues related to liturgy and church music in the Evangelical Church. 2) Conveying viewpoints and evaluation in articles and reader's letters concerning these issues. 3) Showing that there is an ongoing connection between services of the Primitive Church and the Evangelical service of the day, and that the liturgical and church music tradition originates in Jerusalem. ${ }^{12}$

\section{Two Journals in Sweden}

Eventually more Lutheran journals of this type were published in Germany, which followed in the wake of the liturgical and musical renewal efforts that took place in

12 Herold, "Prospectus." 
the nineteenth century. As already mentioned, this also had ripple effects in Scandinavia. ${ }^{13}$ In the following, we shall take a closer look at this development in the light of two Swedish nineteenth-century journals; both of which seem to be inspired by Siona. While the two articles by Herold primarily indicate a framework valid for all genuine church music, the two journals Motettaftonen and Tidning för Kyrkomusik, refer to a more concrete and genre-specific material. The aesthetic basis is, however, easily recognizable from Siona.

\section{Motettaftonen and Tidning för Kyrkomusik}

The first edition of Motettaftonen was published in 1882. To begin with, the journal served as a type of commentary on the programmes of the numerous church concerts that took place in St. Jacob's church in Stockholm at this time. The concert series had a historical profile. The publisher of the journal, Professor Oscar Bernadotte Byström (1821-1909), was a church musician, composer, conductor, pianist, and scholar of historical music. The specialty area of Byström's research was medieval church song. This resulted, among other things, in collections such as "Sekvenser, antifoner och hymner" ["Sequences, Antiphons, and Hymns"] and "Ur medeltidens kyrkosång” ["From Medieval Church Song”]. His interest in chorale history led him to publish several editions of hymnals. The following captions may give an impression of the themes the journal dealt with: "Luther as Reformer of Church Song”, "Our Chorales," "On Purity in the Art of Music," "On Gregorian Chant," and related themes. Even though Byström was interested in old music, the programmes in St. Jacob's bore evidence of a blend of styles. ${ }^{14}$

The stylistic issues were considerably sharpened in the contemporary Tidning för Kyrkomusik, which was published for a period of two years only, between 1881 and 1882. Moreover, this journal must be regarded as the most sterling and serious publication of church music in nineteenth-century Scandinavia. The editor and publisher was one and the same: musikdirektör [musical director] Johan Lindegren (1842-1908). By his contemporaries, he was considered one of the best teachers of music theory, especially within the discipline of classical counterpoint. In counterpoint, he became an important teacher for the famous Swedish composer Hugo

13 Cf. Tandberg, "Fra kirkestil til sjangerpluralisme. Historien som speil for dagens kirkemusikk," 236.

14 Sten Carlsson, "Kyrkomusikaliska tidningar i Sverige under 1800- och 1900-talen. Särskild förteckning över behandlade tidningar i slutet av artikeln," in Sveriges allmänna organist- och kantorsförening. Minnesskrift 1901-1951, eds. David Åhlén, Ernst Andrén and Sten Carlsson (Uppsala: Almqvist \& Wiksells Boktrykkeri Aktiebolag, 1951), 75-6. Cf. Lennart Hedwall, Oscar Byström. Ett svenskt musikeröde från 1800-talet (Hedemora: Gidlunds Förlag, 2003), 285-96. 
Alfvén (1872-1960). Lindegren also served as a church musician in Storkyrkan [today the Cathedral of Stockholm], and he worked as a music teacher at several schools in the Swedish capital. ${ }^{15}$

Already in the first edition, Lindegren raises an interesting discussion. In the article "De liturgiskt-musikaliska sträfvanden" [The Liturgic Musical Efforts], he discusses choral song, which was highly valued by many church music lovers. ${ }^{16}$ Lindegren sides with Byström and wishes for a serious study of the old chorales in their original form. He claims that only such a study can solve what he calls "the chorale problem" (i.e. issues concerning melodic and harmonic structure). On this subject, he declares:

In Germany as well as in France voices are raised, and indeed from the highest cultural quarters. In dedicated words, they praise the diatonic modes for the rich variety of expressions that, by also being used in so-called profane music, would be available for the composer. Considering this, how much more would they not be held in high esteem and be justifiable in their original area, that of church music! ${ }^{17}$

Hymnody or other forms of singing that can be connected with the sanctity of the church, is now treated much more thoroughly than in any other Swedish publication of this period. Much of the material is translations from German journals, most of it probably from Siona, but Lindegren thought that it also concerned Swedish circumstances. Several editions of the journal published articles on "Lifting and Improving Church Song." With its programmatic content, these articles give an impression of the musical conditions in the Swedish national church in the last half of the nineteenth century. Lindegren sees a close connection between religion and music: "therefore there is a genuine, true union between religion and music regarding the latter's elaborate as well as plainer works."18 Furthermore, he makes strict demands on anyone who wants to write or edit church music. It would be necessary for them to have finished thorough studies of music theory (read: harmony and, particularly, classical counterpoint), if he were to achieve anything in this field.

15 Cf. Hugo Alvén, “Min lärare Johan Lindegren," in Musikmänniskor. Personliga minnen av bortgångna svenska tonsättare berättade av 25 författare under redaktion av Folke H. Tömblom, ed. Folke H. Törnblom (Uppsala: J. A. Lindblads Förlag, 1943), 121ff.

16 Johan Lindegren, “De liturgiskt-musikaliska sträfvanden.” Tidning för Kyrkomusik, no. 1 (1881).

17 "Såväl i Tyskland som i Frankrike höjas röster och det från de mest högkonstnärliga håll, hvilka i hängivna ordalag prisar kyrkotonearterna för den uttryckets rika mångfald, som genom deres upptagande, jemväl i s. k. världslig musik, skulle komma att stå tonsättaren til buds. Detta antaget, hvad för ett orubbad anseende och berättigande böra de icke desto mera åtnjuta på deras egentliga urområde; kyrkomusiken." See Carlsson, "Kyrkomusikaliska tidningar," 78.

18 "altså gives det en innerlig, sann förening emellan religion och tonkonst beträffande såväl den senares konstfulla som och enklare alster." See Carlsson, "Kyrkomusikaliska tidningar,” 78. 
In what follows in the article, Lindegren turns to church song in particular. He divides it into artistic singing and unison singing. His definition of artistic singing is: "In this case, artistic singing means a special, prepared and rehearsed delivery of polyphonic religious songs, with or without accompaniment, to open the mind to the truths of religion as well as, through the art of music, awaken the life of beauty, which is also a life of goodness." ${ }^{19}$ He does not think very highly of unison singing in church. He would rather they did not have it. However, he admits: "Unison singing is one of the peculiarities within the Protestant cult, which finds its legitimacy in individualism." 20 Above all, he wants more of artistic singing: "We therefore insist on mixed polyphonic choirs being established, and that there be antiphonal singing between the choir, the minister and the congregation."21

Lindegren also calls upon composers to write new chorale melodies. He himself frequently contributed to this with a large number of newly composed chorales. Furthermore, he writes about liturgical music and points out what qualities should characterize this type of music: "The most important law in the world of music is Beauty." ${ }^{22}$ It is essential for him that such beauty transcend into the sublime. For music to express this, it must have qualities like piety, greatness, and sanctity. According to Lindegren, no style demonstrates such qualities as the Palestrina style: "this school must be regarded as standard and determining for all church music." ${ }^{23}$ He then divides these qualities into subdivisions; however, discussing this further would exceed the limits of this article. ${ }^{24}$

In light of Max Herold's two articles in Siona's first edition, and Oscar Bernadotte Byström's ideas communicated in Motettaftonen, and Johan Lindegren thoughts expressed in Tidning för kyrkomusik, the answer to the question of whether there exists special forms of church music would undoubtedly be in the affirmative. ${ }^{25}$ In their opinion, music has a message, and there is something about how this message is

19 "Med konstsång förstås här ett särskilt förberedt och öfvadt föredrag af flerstämmig kyrklig (religiös) sång, som med eller utan beledsagning, i afsigt såväl att öppna sinnet för religionens sanningar som att genom tonkonsten uppväcka det lif i skönhet som tillika är ett lif i godhet." See Carlsson, "Kyrkomusikaliska tidningar," 78.

20 "Menighetssången är en bland egendomligheterne inom den protestantiska kulten, samt har sitt berättigande i den individuella friheten." See Carlsson, "Kyrkomusikaliska tidningar," 78-9.

21 "Vi yrka altså högeligen på upprättande af fyrstämmiga blandade körer, äfvensom på anordnande av vexelsång emellan kören, presten och församlingen.” See Carlsson, "Kyrkomusikaliska tidningar," 79.

22 “Tonverldens högsta lag är Skönhet." See Carlsson, "Kyrkomusikaliska tidningar,” 79.

23 "hvadan denna rigtning måste anses så som måttgivande och bestämmande för all kyrkomusik." See Carlsson, "Kyrkomusikaliska tidningar," 79.

24 Carlsson, "Kyrkomusikaliska tidningar," 77-80.

25 Cf. Tandberg, "Fra kirkestil til sjangerpluralisme. Historien som speil for dagens kirkemusikk," 231-2. 
communicated that makes it possible to experience the music as sacred and as church music.

In turn, this qualified this music as the bearer of a holy message. Herold, Byström, and Lindegren considered these qualities to be rooted in history, and were of the opinion that these musical qualities had their deepest roots precisely in the ancient temple cult on Mount Zion in Jerusalem. 


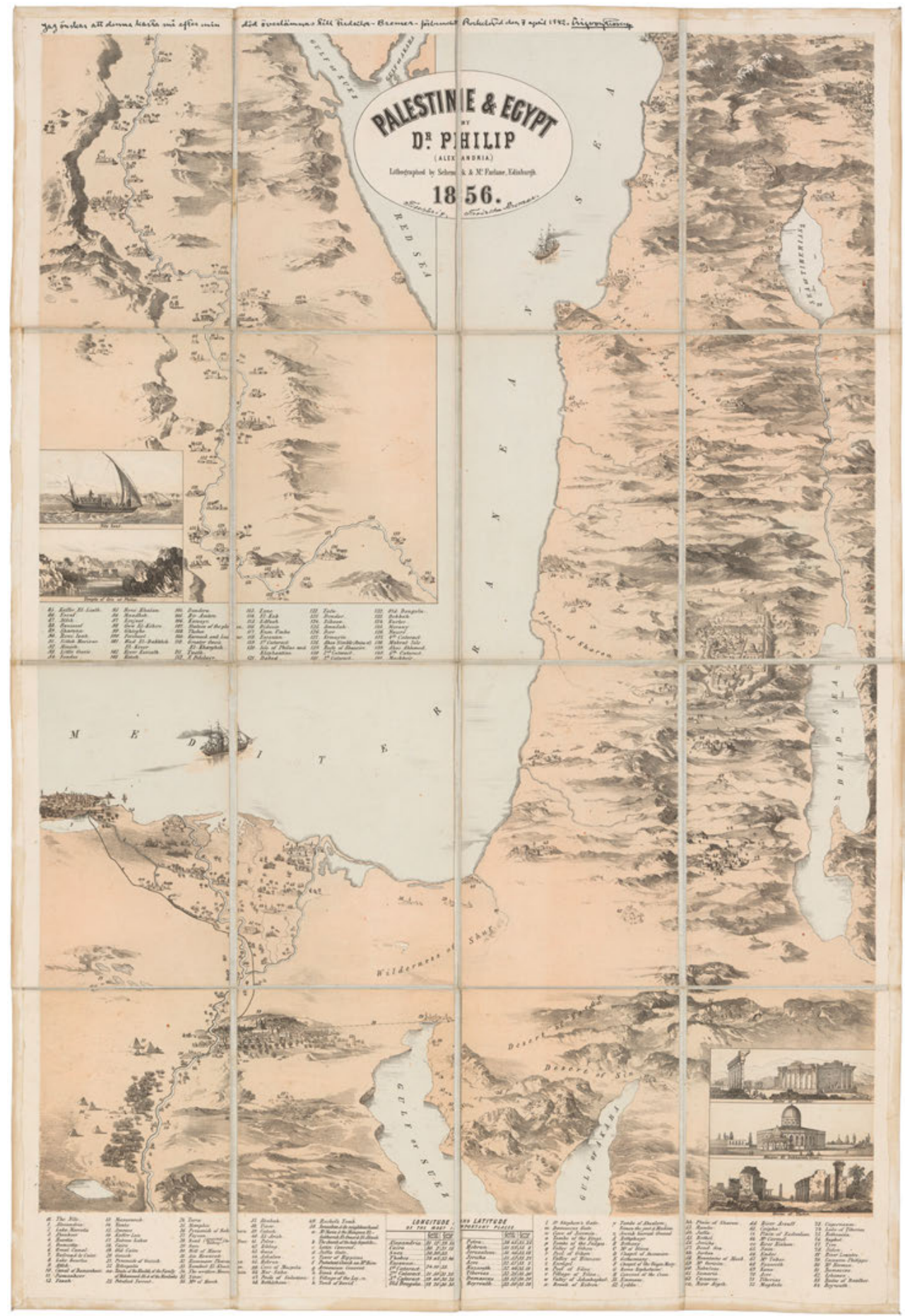

Fig. 15.0: Fredrika Bremer's travel map over Palestine and Egypt. The National Library of Sweden, Stockholm. Photo: Ann-Sofie Persson. 